\title{
A Study of Problem Based Learning and Mathematics Process Skills in Elementary School
}

\section{Kamid1, Husni Sabil2, Wardi Syafmen ${ }^{3}$, Elza Triani ${ }^{4}$}

\author{
1, 2,3,4 Faculty of Teaching and Education. Universitas Jambi, Jambi, Indonesia
}

\section{A R T I C L E I N F O}

Article history:

Received April 08, 2021

Revised April 11, 2021

Accepted April 30, 2021

Available online May 25, 2021

Kata Kunci:

Keterampilan Proses,

Matematika, Problem based learning

Keywords:

Mathematics, Process Skills, Scientific Learning

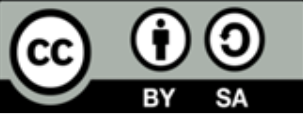

This is an open access article under the CC BY-SA license.

Copyright (C) 2021 by Author. Published by Universitas Pendidikan Ganesho.

A B S T R A C T

\begin{abstract}
ABS TRAK
Proses pembelajaran tidak terlepas dari model pembelajaran, pemilihan model pembelajaran yang baik tentunya akan memberikan efek yang baik terhadap respon siswa serta keterampilan proses siswa serta sebaliknya. Penelitian ini bertujuan menetahui perbandingan keterampilan proses siswa dan respon siswa terhadap model pembelajaran PBL di SD/MI, serta mengetahui hubungan respon peserta didik terhadap respon siswa terhadap model pembelajaran PBL dengan keterampilan proses siswa. Jenis penelitian ini adalah penelitian kuantitatif ekperimen dengan membandingkan 4 kelas yang menggunakan model PBL. Sample pada penelitian ini adalah 144 siswa dari sekolah SD Negeri. Instrumen dalam penelitian ini ada 2 yaitu model Process Skills for Science dan Problem Based Learning (PBL). Terdapat 47 item pertanyaan keterampilan proses dan 26 item pertanyaan dalam model pembelajaran yang menggunakan skala likert 5. Penelitian ini menggunakan analisis data kuantitatif dengan bantuan SPSS statistic 25, untuk mencari statistik deskriptif dan statistik inferensial. Hasil dari uji T menunjukkan bahwa dimasing masing sekolah memiliki perbedaan untuk keterampilan proses dan respon siswa terhadap model pembelajaran PBL Serta, hasil dari uji korelasi dimasing-masing sekolah menunjukan bahwa respon peserta didik terhadap terhadap model pembelajaran PBL berpengaruh terhadap keterampilan proses siswa. Hal ini dapat dilihat dari nilai sig. < 0,05. Jadi, model pembelajaran yang dilakukan disetiap sekolah memberikan pengaruh terhadap respon siswa dan ketreampilan proses, serta terdapat hubungan antara respon siswa dan keterampilan proses.
\end{abstract}

\begin{abstract}
The learning process is inseparable from the learning model, the selection of a good learning model will certainly have a good effect on student responses and student process skills and vice versa. This study aims to determine the comparison of student process skills and student responses to the PBL learning model in SD/MI, and to determine the relationship between student responses to student responses to the PBL learning model and student process skills. This type of research is experimental quantitative research by comparing 4 classes using the PBL model. The sample in this study was 144 students from public elementary schools. There are 2 instruments in this research, namely Process Skills for Science and Problem Based Learning (PBL) models. There are 47 items of process skills questions and 26 items of questions in the learning model that uses a Likert scale 5 . This study uses quantitative data analysis with the help of SPSS statistics 25 , to find descriptive statistics and inferential statistics. The results of the T test showed that in each school there were differences in process skills and student responses to the PBL learning model. Also, the results from the correlation test in each school showed that students' responses to the PBL learning model had an effect on students' process skills. This can be seen from the value of sig. $<0.05$. So, the learning model carried out in each school has an influence on student responses and process skills, and there is a relationship between student responses and process skills.
\end{abstract}

\section{INTRODUCTION}

Education is a necessity for every human being. Education is a learning process to acquire knowledge, skills, attitudes and thinking skills that is carried out by a person (Abbas \& Hidayat, 2018; Hidayat, 2017; Rosidin et al., 2019). Education in a country automatically also shows the progress of a 
country. Education is ideally something that is very important in developing attitudes and skills (Astalini et al., 2018; Campbell et al., 2017; Putri et al., 2020). Quality education is a picture of the success of a nation (Duma et al., 2021; Joarder et al., 2020; Mahartika \& Dewantoro, 2017). Education is good for learning success if learning goes well then education will follow. Education is obtained from a learning process where education can be obtained formally or non-formally, one of which is taking education starting from elementary school (SD). At the elementary school level students are taught 9 subjects, one of which is mathematics. One of the subjects considered difficult by students is mathematics. Mathematics is an exact science that studies thinking patterns, logical proofs, organizing patterns and several concepts (Aditya, 2018; Edwards, 2019; Nurhikmayati, 2019). From a series of subjects studied by students, mathematics is one of the most important sciences in the world of education that must be studied (Arifin \& Herman, 2018; Meylinda \& Surya, 2017; Usman Fauzan \& Aldila Afriansyah, 2017). Each individual has a different ability to master mathematical concepts, so it is very influential on the ability to solve problems or math problems. Most students still think that Mathematics is considered difficult so it is less attractive (Arifah et al., 2019; Das, 2020; Surya \& Syahputra, 2017). In mathematics, students need process skills so that it is easier to understand the lesson.

Process skills can be learned by students at the school level. For this reason, having learning process skills that enable students to acquire and apply the knowledge provided by educators. The $21 \mathrm{st}$ century is referred to as the century of knowledge, challenges in an increasingly dynamic and increasingly advanced knowledge era require human resources (Banggur et al., 2018; Mieghem et al., 2020; Ramadhani, 2017). Sophistication of technology that can study a material, especially in physics. Multimedia technology is developing with rapidly growing science and technology (Nurzaelani et al., 2018; Shin \& Bolkan, 2021; Sökmen, 2019). 21st century skills have several features to require students to think critically (Dishon \& Gilead, 2020; N. Pratiwi \& Mustadi, 2021; Rusmono \& Alghazali, 2019). Each individual has different skills. One of the subjects in mathematics at the elementary level is multiplication of fractions. Fractions are one of the core studies of the mathematics curriculum studied in elementary school with discussion of material on working on basic arithmetic operations, namely subtraction, addition, division, and multiplication, so that the majority of students find fractions to be too difficult and complex. by students is still low (Prihanto \& Yunianta, 2018; Santi et al., 2019; Suarsana \& Pujawan, 2017). One of the most important factors that influence the success of learning is the educator with the models, methods, and learning media that support the success of teaching.

In education there is a learning activity that affects students' academics. Learning is basically not just learning about concepts, theories and facts, but is more concerned with applications in everyday life (Evi Marlina, 2021; Hadi Santosa et al., 2018; Siang et al., 2017). Learning activities show a progress in students. Students in learning have their own styles that increase student motivation, increase creativity, so that the learning process can explore developments (Banggur et al., 2018; Rienties et al., 2018; Solihatin, 2017). In the education variable, performance and strategy are very important learning activities to evaluate (Alhassan, 2019; Annisa et al., 2021; De Bruyckere \& Kirschner, 2017). Interesting learning can be caused by the learning model. The learning model is one of the things that need to be known in the teaching and learning process. One of the learning strategies that are considered to be able to improve students' problem solving abilities is Problem Based Learning (PBL) (Astriani et al., 2017; Eviyanti et al., 2017; Rustam E et al., 2017). PBL is learning centered on a learning approach based on analysis, completion and discussion of a given problem (Aini et al., 2019; Amalia et al., 2017; Masitoh \& Fitriyani, 2018). Problem-based learning as a learning approach that begins by presenting a problem is designed in a context that is relevant to the material to be studied to encourage students to: acquire knowledge and understanding of concepts (Malmia et al., 2019; Maskur et al., 2020; Mulyanto et al., 2018). The learning model is very influential on subjects that are considered difficult by students.

This study is in line with previous research conducted by Yulianto et al., (2019), which aims to determine the appropriate learning model for students when participating in learning, but the difference is in previous studies analyzing the influence of the PBL learning model on students' higher thinking skills, not analyzing how students respond and also analyzing how the relationship between student learning models with student process skills in learning activities. As for the limitations of this previous study, the researcher has not conducted extensive research. For this reason, this research was conducted as an update of previous research. In previous research which has similarities with research conducted at this time, namely discussing student learning process skills, the difference is that this previous research only used a relatively small sample and in this previous study aimed to determine the improvement of student learning with the application of the process skills approach as well as in previous research has also only been studied in science subjects (Dewi \& Rati, 2017). So the current research is an update of previous research. This type of research article is the result of research conducted at SD Negeri 156/I Bulian Baru and SD Negeri 001/I Pasar Muara Tembesi and MIS Darul Aufa and MIS Nurul Jadid. Based on this, it is 
important to conduct further research with other skill indicators and to find out the learning model and process skills that affect student responses in learning activities. The purpose of this study is to determine the process skills of students in learning mathematics and the appropriate learning model to be used in mathematics subjects with multiplication of fractions.

\section{METHOD}

This type of research is experimental quantitative research by comparing 4 classes using the PBL model with the volume of blocks and cubes. This research was conducted in 4 schools, namely 2 SD and 2 MI with 36 students in each class. So that the total number of students is this research using a type of comparative quantitative research. A procedure design in quantitative research in which you administer a questionnaire to a small group of people (called a sample) to identify trends in attitudes, opinions, behaviors, or characteristics of a large group of people (Creswell, 2015).

The sample in this study was 144 students from SD Negeri 156/I Bulian Baru and SD Negeri 001/I Pasar Muara Tembesi and MIS Darul Aufa and MIS Nurul Jadid. The population is the person who is the subject of the research to be studied (Banks et al., 2018; Novianti et al., 2019; Sari et al., 2020). The sampling technique is purvosive sampling. Purposive sampling is a type of sampling where the research is more of a case that is less self-selected (M \& Willis, 2004). The reason for taking this technique is because not all samples have criteria that match the exact phenomenon. The samples taken were class VII A and VII B. The research samples used in this study is shown in Table 1.

Table 1. Research Sample

\begin{tabular}{cccccccc}
\hline \multicolumn{2}{c}{$\begin{array}{c}\text { SD Negeri 156/I } \\
\text { Bulian Baru }\end{array}$} & \multicolumn{2}{c}{$\begin{array}{c}\text { SD Negeri 001/I Pasar Muara } \\
\text { Tembesi }\end{array}$} & \multicolumn{2}{c}{ MIS Darul Aufa } & \multicolumn{2}{c}{ MIS Nurul Jadid } \\
\hline V A & V B & V A & V B & V A & V B & V A & V B \\
\hline 36 & 36 & 36 & 36 & 36 & 36 & 36 & 36 \\
\hline
\end{tabular}

There are 2 instruments in this study, namely Process Skills for Science and Problem Based Learning (PBL) models. The assessment instrument is one of the latest experimental assessment instruments in the field of assessment (Caltagirone et al., n.d.; Purwanti et al., 2020) . There are 47 process skills question items and 26 question items in the learning model that uses a Likert 5 scale. The scale consists of 5 points for the learning model with 1 (very bad), 2 (not good), 3 (fairly good), 4 (good), 5 (very good), while 4 points for process skills with 1 (very not good), 2 (not good), 3 (good), and 4 (very good). Each statement is representative of each indicator of process skills and learning models. The lattice of the process skills questionnaire instrument used in this study is shown in Table 2. The categories of process skills used in this study is shown in Table 3.

Table 2. Grid of the process skills observation sheet on mathematics material for Elementary School Students and MIS

\begin{tabular}{lll}
\hline Variables & Indicator & No. Statement Items \\
\hline Mathematical Process Skills for & Measure & $13,14,15$ \\
Multiplication of Fractions & compiling table & $25,26,27$ \\
& Obtain and process data & $28,29,30,31$ \\
\hline & Number of statements & $\mathbf{4 7}$ \\
\hline
\end{tabular}

Table 3. Category Student Science Process Skills

\begin{tabular}{cccc}
\hline \multirow{2}{*}{ Kategori } & \multicolumn{3}{c}{ Indicator interval } \\
\cline { 2 - 4 } & Basic & \multicolumn{2}{c}{ Integration } \\
\cline { 2 - 4 } Not very good & $3.0-5.3$ & $3.0-5.3$ & Obtain and process data \\
Not good & $5.4-7.6$ & $5.4-7.6$ & $4-7$ \\
Good & $7.7-10$ & $7.7-10$ & $8-11$ \\
Very good & $10.1-12.4$ & $10.1-12.4$ & $12-15$ \\
\hline
\end{tabular}

This study uses quantitative data analysis with the help of SPSS 25 statistics, to find descriptive statistics and inferential statistics. According to (M. Muchson, 2017) descriptive statistics discusses ways of collecting, summarizing, presenting data so that information is easier to understand.. At the data collection stage, questionnaires were given to 144 students in two schools, namely SD Negeri 156/I Bulian 
Baru and SD Negeri 001/I Pasar Muara Tembesi as well as MIS Darul Aufa and MIS Nurul Jadid. From the data, data analysis was then carried out, namely data coding, data filtering and data analysis. In analyzing the data of this study, the researcher used descriptive statistics of mean, median, min, max, frequency, and percent. then on inferential statistics the researcher uses an assumption test which consists of a normality test with the condition that the data are normally distributed if the value of sig. $>0.05$ and linearity test with the condition that the data is directly related if the value of sig. $<0.05$ after the further assumption test is fulfilled, the hypothesis test consists of a T test where there is a difference in the data if the value of sig. ( 2 -tailed) $<0.05$, and a correlation test where the data is relationship if the value of sig. $(2$-tailed) $<0.05$. So that a conclusion can be drawn.

In collecting data in the form of attitude activities carried out using descriptive statistics based on the categories given by the researcher. An overview or presentation of large amounts of data that includes the mean, mode, median, max. min, and the standard deviation is a descriptive statistic (Pramesti, 2018; Santoso, 2019; Wahyuni, 2020). The data needed in this research was collected and obtained from SD Negeri 156/I Bulian Baru and SD Negeri 001/I Pasar Muara Tembesi as well as MIS Darul Aufa and MIS Nurul Jadid. There is also the procedure for collecting data in this study in accordance with the following diagram 1.
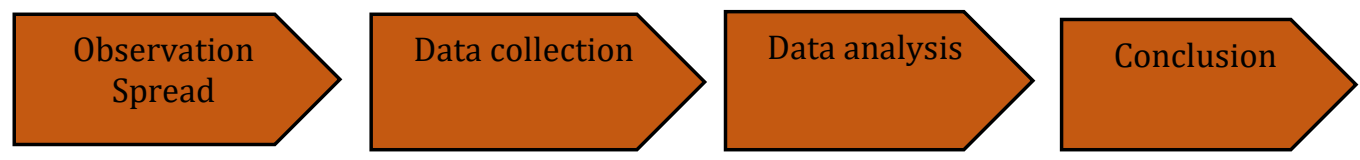

Figure 1. Research Procedure.

\section{RESULT AND DISCUSSION}

\section{Result}

Results are the main part of scientific articles, containing: clean results without data analysis process, results of hypothesis testing. Results can be presented with tables or graphs, to clarify the results verbally. Discussion is the most important part of the overall content of scientific articles. The objectives of the discussion are: Answering research problems, interpreting findings, integrating findings from research into existing knowledge sets and developing new theories or modifying existing theories..

\section{Descriptive Statistics Test}

The description of the process skills of SD/MI students on the multiplication of indicator fractions material obtains and processes data. The process skills of SD/MI students with indicators of obtaining and processing data, it was found that the average number of students chose the good category with the percentage for SD N 156 29.2\% good, SDN 04 29.2\% good, MIS DA $29.2 \%$ good, MIS NJ 29.2\% good. The description of the process skills of SD/MI students on the multiplication of fractions material on measuring indicators is as follows teble 5. The process skills of SD/MI students with measuring indicators found that on average many students chose the good category with the percentage for SD N $15648.6 \%$ good, SD N 001 33.3\% good, MIS Darul Aufa 34.7 \% good, MIS NJ 33.3\% good. The description of the process skills of SD/MI students on the multiplication of indicator fraction materials. Arrange a table like the following table 6 . The process skills of SD/MI students with indicators Compiling the table it was found that the average number of students chose the good category with the percentage for SD N 156 47.2\% good, SD N 001 47.2\% good, MIS DA 43.1\% good, MIS NJ 47.2\% good. The description of the PBL learning model for the multiplication of fractions material is as follows table 7 . Based on the description of student responses after studying with the PBL learning model above, it was found that at SD Negeri 156/I Bulian Baru, the dominant category was good with a percentage of 58.3\%, then at SD Negeri 001/I Pasar Tembesi was dominant in the good category with a good percentage, then MIS Darul Aufa is dominant in the good category with a percentage of $62.5 \%$, then at MIS Nurul Jadid is dominant in the good category with a percentage of $63.9 \%$.

\section{Assumption test}

In the assumption test, a normality test is carried out which serves to see whether the data is normally distributed or not, and also a linearity test which functions to see the linear relationship between the two variables to be tested. 1) Normality test is a test that is useful for determining the data that has been collected is normally distributed or not. The data requirements are said to be normally distributed if the value of sig. $>0.05$. The description of the results for the normality test of students' process skills with fraction multiplication material at SDN 156/I Bulian Baru and MIS Nurul Jadid is shown in the Table 4 . The results of the normality test are that the significance value is $>0.05$, it can be concluded 
that the data on student process skills and student responses to the PBL model in mathematics subjects with fraction multiplication material in SD/MI are normally distributed. 2) Linearity test is a test used to determine the form of the relationship between the independent variable or the dependent variable. The data conditions are said to be related if the value of sig. $<0.05$. The description of the results for the linearity test of students' process skills and student responses after learning with the PBL model with multiplication of class fractions material in SD/MI is shown in the table 5. The results of the linearity test are obtained, namely the significance value $<0.05$, it can be concluded that there is a linear relationship between student process skills and student responses to the PBL model in mathematics subjects with fraction multiplication material in SD/MI.

Table 4. Description of the results for the normality test of students' process skills and students' responses to the PBL model in mathematics subjects with multiplication of fractions in SD/MI

\begin{tabular}{cccc}
\hline Variable & School Name & Sig. & Distribute \\
\hline \multirow{2}{*}{ Process Skills } & SD Negeri 156/I Bulian Baru & .300 & Normal \\
& SD Negeri 001/I Pasar Muara Tembesi & .300 & Normal \\
& MIS Nurul Jadid & .200 & Normal \\
& MIS Darul Aufa & .100 & Normal \\
PBL & SD Negeri 156/I Bulian Baru & .200 & Normal \\
& SD Negeri 001/I Pasar Muara Tembesi & .100 & Normal \\
& MIS Nurul Jadid & .200 & Normal \\
& MIS Darul Aufa & .100 & Normal \\
\hline
\end{tabular}

Table 5. description of the results for the linearity test of students' process skills and student responses to the PBL model in mathematics subjects with multiplication of fractions in SD/MI

\begin{tabular}{cclc}
\hline Variable & School Name & Sig. & Distribute \\
\hline Process & SDN 156/I Bulian Baru & 0,035 & linear \\
Skills*Student & SD Negeri 001/I Pasar Muara Tembesi & 0,037 & linear \\
responses to & MIS Nurul Jadid & 0,035 & linear \\
the PBL model & MIS Darul Aufa & 0,044 & linear \\
\hline
\end{tabular}

\section{Hypothesis test}

In this hypothesis test, the tests carried out are $\mathrm{T}$ test and correlation test. The $\mathrm{t}$ test aims to determine whether the independent variable has an effect on the dependent variable while the correlation test aims to determine the relationship between process skills and the PBL model on the multiplication of fractions material. The description of the results for the T-test of students' process skills on mathematics subjects with the Multiplication of Fractions material in SD/MI is shown in the Table 6. The results of the T test are obtained, namely the value of sig. (2-tailed) $<0.05$, it can be concluded that there are differences in students' processing skills in the multiplication of fractions material in SD/MIS. The description of the results for the T-test of student responses to the PBL model on velocity and discharge material in SD/MI is shown in the Table 7. The results of the T test are obtained, namely the value of sig. (2-tailed $<0.05$, it can be concluded that there are differences in student responses to the PBL model on the multiplication of fractions material in SD/MIS. The description of the results for the correlation test between students' process skills and student responses to the PBL model with fraction multiplication material in SD/MI is shown in the Table 8 . The result of the correlation test is the value of sig. $(2$-tailed) $<0.05$, it can be concluded that there is a relationship between student process skills and student responses to the PBL model with fractional multiplication material.

Table 6. T-test description of students' process skills towards mathematics lessons with multiplication of fractions in SD/MI

\begin{tabular}{|c|c|c|}
\hline School Name & Class & Sig.(2-tailed) \\
\hline SDN 156/I Bulian Baru & $\begin{array}{l}\text { VA } \\
\text { VB }\end{array}$ & 0,029 \\
\hline SD Negeri 001/I Pasar Muara Tembesi & $\begin{array}{l}\text { V A } \\
\text { V B }\end{array}$ & 0,037 \\
\hline MIS Nurul Jadid & $\begin{array}{l}\text { V A } \\
\text { V B }\end{array}$ & 0,039 \\
\hline MIS Darul Aufa & $\begin{array}{l}\text { V A } \\
\text { V B }\end{array}$ & 0,023 \\
\hline
\end{tabular}


Table 7. T-test description of student responses to the PBL model on fraction multiplication material in $\mathrm{SD} / \mathrm{MI}$

\begin{tabular}{llc}
\hline School Name & Class & Sig.(2-tailed) \\
SDN 156/I Bulian Baru & V A & 0,029 \\
SD Negeri 001/I Pasar Muara Tembesi & V B & \multicolumn{2}{c}{0,047} \\
MIS Nurul Jadid & V B & \\
& V A & 0,039 \\
MIS Darul Aufa & V B & \multicolumn{2}{c}{0,033} \\
\hline
\end{tabular}

\section{Correlation Test}

Tabel 8. Description of the correlation test of students' process skills and student responses to the PBL model with fraction multiplication material in SD/MI

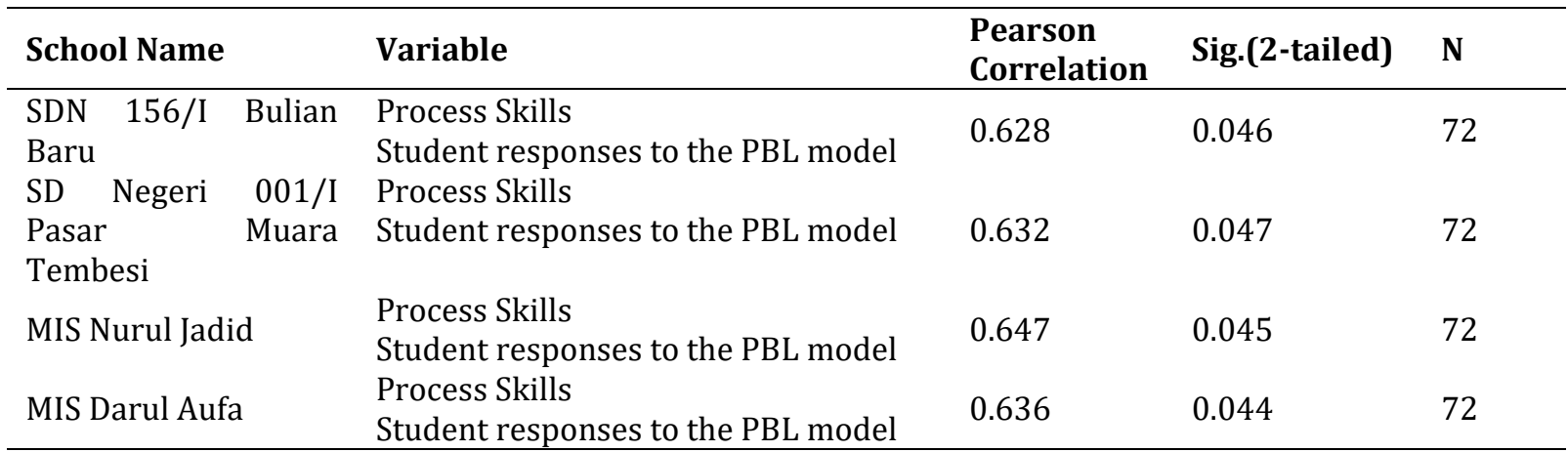

\section{Discussion}

From these results, it can be seen that the indicators of obtaining and processing data, both SD and MI, dominantly have good skills, on the indicator measuring SD N $15648.6 \%$ have a good percentage in measuring skills higher than other schools. On indicators Compile tables SD N 156, SD N 001, MIS NJ with a greater and the same percentage in the good category. Then the students' responses after learning to use the Problem Based Learning (PBL) model for all classes were categorized as good, with the highest percentage being MIS Nurul Jadid. This is inseparable from the learning process carried out with PBL, where the learning process with this model will provide opportunities for students to be more active in the learning process and the problems found in everyday life. PBL employs constructivist principles to foster application of prior knowledge, collaborative learning, and active engagement (Seibert, 2021). In the learning process with the PBL model students will analyze problems, identify relevant facts and apply knowledge and experience to solve problems(Zhou, 2018). The problem in a PBL activity should be a typical, work-related issue or situation that includes missing information or unclear answers such as illstructured case studies(Miner-Romanoff et al., 2019). By learning using problem-based learning models can improve critical thinking skills(Abdulah et al., 2021; Narmaditya et al., 2018), improve learning outcomes(Hidayati \& Wagiran, 2020; V. D. Pratiwi \& Wuryandani, 2020; Qomariyah, 2019). So, it can be said that the application of the problem-based learning model has a positive influence on the learning process, both the response of students in participating in learning and learning outcomes.

Based on the results of the study, it was obtained that there are differences in students' process skills in the fraction multiplication material in SD/MIS student responses to the fraction multiplication material in the learning model Problem based learning. This is of course inseparable from the steps of problem-based learning, students are required to solve the given problem by carrying out a clear process that is accommodated by the knowledge and experience of students will be able to develop process skills in solving the given problem. Process skills can be learned by students at the school level. For this reason, having learning process skills that enable students to acquire and apply the knowledge provided by educators. The 21st century is referred to as the century of knowledge, challenges in an increasingly dynamic and increasingly advanced knowledge era require human resources (Banggur et al., 2018; Mieghem et al., 2020; Ramadhani, 2017). Sophistication of technology that can study a material, especially in physics. Multimedia technology is developing with rapidly growing science and technology (Nurzaelani et al., 2018; Shin \& Bolkan, 2021; Sökmen, 2019). 21st century skills have several features to require students to think critically (Dishon \& Gilead, 2020; N. Pratiwi \& Mustadi, 2021; Rusmono \& Alghazali, 
2019). Each individual has different skills. So, it is very important to choose a learning model that is in accordance with the characteristics of students, which will make students happier in participating in the learning provided. The results of the correlation test between process skills and student responses after learning with the PBL model on the material multiplication of fractions at SDN 156/I Bulian Baru it can be concluded that there is a relationship between student responses to the PBL model and students' processing skills in fractional multiplication material. Student responses to the learning model will greatly affect the learning process if the response is positive then the learning process will also be good this will have an impact on student process skills. Student responses and incorrect skills are related to learning outcomes. Student responses and good process skills will have a positive influence on learning outcomes. Good learning outcomes will be obtained from the learning process that gives students the opportunity to build their own knowledge. By building their own knowledge, the learning process will be more meaningful.

In previous research stated the results of his research that the learning model had an effect on student learning outcomes (Qomariyah, 2019), this was in line with the research conducted in this article, but in other previous study only tested the hypothesis T test. the sample used came from one school, namely high school in class IX IPS (Qomariyah, 2019). This research is in line with previous research examining student process skills but in this article examines process skills in mathematical thinking and the sample used in this study is at the tertiary education level with a total of 27 students (Ulya \& Rahayu, 2021). For this reason, this study was conducted as an update of previous research with a sample of 288 which was conducted in two SD and two MIS to determine the difference in student process skills in SD and MIS, as well as to determine the relationship between student process skills and student responses to the PBL learning model in mathematics. with fraction multiplication material.

In this study, the aim of this study was to find out the comparison and relationship between students' process skills and student responses after learning with the Problem Based Learning model at SDN and also at MIS in mathematics subjects with fraction multiplication material. With indicators of measuring process skills, developing measuring skills is the most important thing in fostering quantitative observations, classifying, comparing everything around us (length, area, volume, etc.), then integrated indicators, namely Compiling tables students can classify things using tables systematically. systematically, then indicators obtain and process data where students are able to obtain data from an observation and can analyze the data so as to produce a discovery or problem solving. The limitation of this article is that it only measures one learning model with general indicators. The indicators used in the process skills variable are measuring, compiling tables, and obtaining and processing data. However, this research needs to be done to determine student responses after learning with the PBL learning model, to know the process skills possessed by students, and also as a reference for educators to teach using the right model in learning activities. The researcher suggests conducting further research to compare the models in learning mathematics with other materials and the researcher suggests researching at the junior high or high school education level.

\section{CONCLUSION}

The application of the Problem Based Learning (PBL) learning model has a positive impact on the learning process in terms of student response and process skills. These aspects have a positive relationship to learning outcomes. Student responses and good skills learning outcomes will also be good. By using the Problem Based Learning (PBL) learning model, students will follow the learning well.

\section{REFERENCES}

Abbas, \& Hidayat, M. Y. (2018). Faktor-Faktor Kesulitan Belajar Fisika Pada Peserta Didik. Jurnal Pendidikan Fisika, 6(1), 45-49.

Abdulah, A., Mustadi, A., \& Fitriani, W. (2021). PBL-Based Interactive Multimedia in Improving Critical Thinking Skills. JPI (Jurnal Pendidikan Indonesia), 10(1), 136. https://doi.org/10.23887/jpiundiksha.v10i1.25521.

Aditya, P. T. (2018). Pengembangan Media Pembelajaran Matematika Berbasis Web Pada Materi Lingkaran Bagi Siswa Kelas VIII. Jurnal Matematika Statistik \& Komputasi, 15(1), 64-74.

Aini, N. R., Syafril, S., Netriwati, N., Pahrudin, A., Rahayu, T., \& Puspasari, V. (2019). Problem-Based Learning for Critical Thinking Skills in Mathematics. Journal of Physics: Conference Series, 1155(1). https://doi.org/10.1088/1742-6596/1155/1/012026.

Alhassan, A. (2019). Investigating business EFL postgraduate student writing in a UK university: a qualitative study. Cogent Education, 6(1). https://doi.org/10.1080/2331186X.2019.1699741. 
Amalia, E., Surya, E., \& Syahputra, E. (2017). The Effectiveness Of Using Problem Based Learning (Pbl) In Mathematics Problem Solving Ability For Junior High School Students. Ijariie, 3(2), 3402-3406.

Annisa, M., Abrori, F. M., Alwahid, S. M., Nordiansyah, M., Risma, R., Hasbiah, H., Amelia, D. P., \& Gita, S. D. (2021). The Process Skills Approach with Mind Map Media Through Lesson Study Improving Students' Learning Outcomes. JPI (Jurnal Pendidikan Indonesia), 10(1), 57. https://doi.org/10.23887/jpi-undiksha.v10i1.17320.

Arifah, R. E. N., Sukirman, S., \& Sujalwo, S. (2019). Pengembangan Game Edukasi Bilomatika untuk Meningkatkan Hasil Belajar Siswa pada Mata Pelajaran Matematika Kelas 1 SD. Jurnal Teknologi Informasi Dan Ilmu Komputer, 6(6), 617. https://doi.org/10.25126/jtiik.2019661310.

Arifin, F., \& Herman, T. (2018). Pengaruh Pembelajaran E-Learning Model Web Centric Course Terhadap Pemahaman Konsep Dan Kemandirian Belajar Matematika Siswa. Jurnal Pendidikan Matematika, 12(2), 1-12.

Astalini, A., Kurniawan, D. A., \& Putri, A. D. (2018). Identifikasi Sikap Implikasi Sosial dari IPA, Ketertarikan Menambah Waktu Belajar IPA, dan Ketertarikan Berkarir Dibidang IPA Siswa SMP Se-Kabupaten Muaro Jambi. Jurnal Tarbiyah: Jurnal Ilmiah Kependidikan, 7(2), 93-108. https://doi.org/10.18592/tarbiyah.v7i2.2142.

Astriani, N., Surya, E., \& Syahputra, E. (2017). The Effect Of Problem Based Learning To Students' Mathematical Problem Solving Ability. International Journal Of Advance Research And Innovative Ideas In Education, 3(2), 3441-3446.

Banggur, M. D. V., Situmorang, R., \& Rusmono, R. (2018). Pengembangan Pembelajaran Berbasis Blended Learning Pada Mata Pelajaran Etimologi Multimedia. JTP - Jurnal Teknologi Pendidikan, 20(2), 152-165. https://doi.org/10.21009/jtp.v20i2.8629.

Banks, H. T., Flores, K. B., Langlois, C. R., Serio, T. R., \& Sindi, S. S. (2018). Estimating the rate of prion aggregate amplification in yeast with a generation and structured population model. Inverse $\begin{array}{llll}\text { Problems in Science 257-279. } & \text { and }\end{array}$ https://doi.org/10.1080/17415977.2017.1316498.

Caltagirone, C., Razzano, C., \& Lucia, F. S. (n.d.). Psicologia e psicobiologia dell'apprendimento.

Campbell, C., Pollock, K., Briscoe, P., Carr-Harris, S., \& Tuters, S. (2017). Developing a knowledge network for applied education research to mobilise evidence in and for educational practice. Educational Research, 59(2), 209-227. https://doi.org/10.1080/00131881.2017.1310364.

Creswell, J. W. (2015). Penelitian Kualitatif \& Desain Riset. Mycological Research, 94(4), 522.

Das, K. (2020). Role of ICT for Better Mathematics Teaching. Shanlax International Journal of Education, 7(4). https://doi.org/10.34293/education.v7i4.641.

De Bruyckere, P., \& Kirschner, P. A. (2017). Measuring teacher authenticity: Criteria students use in their perception of teacher authenticity. Cogent Education, 4(1). https: //doi.org/10.1080/2331186X.2017.1354573.

Dewi, A. A. S. P. M., \& Rati, N. W. (2017). Penerapan Pendekatan Keterampilan Proses Untuk Meningkatkan Hasil Belajar Siswa Pada Materi Energi Bunyi. Jurnal Ilmiah Sekolah Dasar, 2(1), 83-90. https://doi.org/10.33086/ehdj.v2i1.376.

Dishon, G., \& Gilead, T. (2020). Adaptability And Its Discontents : 21st- Century Skills And The Preparation For An Unpredictable Future. British Journal of Educational Studies, 00(00), 1-21. https://doi.org/10.1080/00071005.2020.1829545.

Duma, S., Limbong, M., \& Kailola, L. G. (2021). Pengaruh Kompetensi Profesional Guru , Motivasi Belajar terhadap Hasil Belajar Siswa di Sekolah Menengah Kejuruan Kristen. Jurnal Pendidikan Tambusai, $5,815-826$.

Edwards, H. M. (2019). The Role of History in the Study of Mathematics. Mathematical Intelligencer, 10-13. https://doi.org/10.1007/s00283-019-09947-y.

Evi Marlina, M. A. (2021). Developing Students' Soft Skills Through Group-Work Method in Cost Accounting Learning. JPI (Jurnal Pendidikan Indonesia), 10(1), 34. https://doi.org/10.23887/jpiundiksha.v10i1.24994.

Eviyanti, C. Y., Surya, E., Syahputra, E., \& Simbolon, M. (2017). Improving the Students' Mathematical Problem Solving Ability by Applying Problem Based Learning Model in VII Grade at SMPN 1 Banda Aceh Indonesia. International Journal of Novel Research in Education and Learning, 4(2), 138-144.

Hadi Santosa, F., Umasih, U., \& Sarkadi, S. (2018). Pengaruh Model Pembelajaran dan Kemampuan Berpikir Kritis Terhadap Hasil Belajar Sejarah Siswa di SMA Negeri 1 Pandeglang. JTP - Jurnal Teknologi Pendidikan, 20(1), 13-27. https://doi.org/10.21009/jtp.v20i1.6777.

Hidayat, W. (2017). Adversity Quotient Dan Penalaran Kreatif Matematis Siswa Sma Dalam Pembelajaran Argument Driven. Jurnal Pendidikan Matematika, 2(1), 15-28. 
Hidayati, R. M., \& Wagiran, W. (2020). Implementation of problem-based learning to improve problemsolving skills in vocational high school. Jurnal Pendidikan Vokasi, 10(2), 177-187. https://doi.org/10.21831/jpv.v10i2.31210.

Joarder, M. H. R., Ashraf, M. A., \& Ratan, S. R. A. (2020). Quality education from faculty management perspectives in private higher education: Does faculty commitment behaviour mediate? International Journal of Education and Practice, 8(1), 190-206. https://doi.org/10.18488/journal.61.2020.81.190.206.

M. Muchson. (2017). Statistik Deskriptif. Guepedia.

M, S., \& Willis, C. (2004). Clinical Research, Concepts and Principles for Advanced Practice Nurses. Lippincott Williams.

Mahartika, A. S., \& Dewantoro, D. A. (2017). Meningkatkan Kemampuan Membaca Pemahaman Anak Tunagrahita Ringan dengan Menggunakan Metode Reading Aloud. Jurnal ORTOPEDAGOGIA, 3(2), 123-126. https://doi.org/10.17977/um031v3i22017p123.

Malmia, W., Makatita, S. H., Lisaholit, S., Azwan, A., Magfirah, I., Tinggapi, H., \& Umanailo, M. C. B. (2019). Problem-based learning as an effort to improve student learning outcomes. International Journal of Scientific and Technology Research, 8(9), 1140-1143. https://doi.org/10.5281/zenodo.3457426.

Masitoh, L. F., \& Fitriyani, H. (2018). Malikussaleh journal of mathematics learning : MJML. Malikussaleh Journal of Mathematics Learning (MJML), 1(1), 26-30.

Maskur, R., Sumarno, Rahmawati, Y., Pradana, K., Syazali, M., Septian, A., \& Palupi, E. K. (2020). The effectiveness of problem based learning and aptitude treatment interaction in improving mathematical creative thinking skills on curriculum 2013. European Journal of Educational Research, 9(1), 375-383. https://doi.org/10.12973/eu-jer.9.1.375.

Meylinda, D., \& Surya, E. (2017). Kemampuan koneksi dalam pembelajaran matematika di sekolah. Jurnal Pendidikan Matematika, December, 1-10.

Mieghem, A. Van, Struyf, E., \& Verschueren, K. (2020). The relevance of sources of support for teachers ' self-efficacy beliefs towards students with special educational needs. European Journal of Special Needs Education, 00(00), 1-15. https://doi.org/10.1080/08856257.2020.1829866.

Miner-Romanoff, K., Rae, A., \& Zakrzewski, C. (2019). A Holistic and Multifaceted Model for Ill-Structured Experiential Problem-Based Learning: Enhancing Student Critical Thinking and Communication Skills. Journal of Problem Based Learning in Higher Education, 7(1), 70-96. https://doi.org/10.5278/ojs.jpblhe.v7i1.3341.

Mulyanto, H., Gunarhadi, G., \& Indriayu, M. (2018). The Effect of Problem Based Learning Model on Student Mathematics Learning Outcomes Viewed from Critical Thinking Skills. International Journal of Educational Research Review, 3(2), 37-45. https://doi.org/10.24331/ijere.408454.

Narmaditya, B. S., Wulandari, D., \& Sakarji, S. R. B. (2018). Does Problem-based Learning Improve Critical Thinking Skills? Cakrawala Pendidikan, 37(3), 378-388.

Novianti, R. W., Triwani, T., \& Roflin, E. (2019). Characteristic Patients With Urogenital System Congenital Abnormalities in At Rsmh Palembang. Majalah Kedokteran Sriwijaya, 51(2), 97-106. https://doi.org/10.32539/mks.v51i2.8542.

Nurhikmayati, I. (2019). Implementasi STEAM. Jurnal Didactical Mathematics, 1(2), 41-50.

Nurzaelani, M. M., Kasman, R., \& Achyanadia, S. (2018). Pengembangan Bahan Ajar Integrasi Nasional Berbasis Mobile. Jurnal Teknologi Pendidikan, 20(3).

Pramesti, G. (2018). Mahir Mengolah Data Penelitian dengan SPSS. PT. Elex Media Komputindo.

Pratiwi, N., \& Mustadi, A. (2021). Hots-Based Learning in 2013 Curriculum: Is it Suitable? Jurnal Pendidikan Indonesia (JPI), 10(1), 128-135. https://doi.org/10.23887/jpi-undiksha.v10i1.22781.

Pratiwi, V. D., \& Wuryandani, W. (2020). Effect of Problem Based Learning (PBL) Models on Motivation and Learning Outcomes in Learning Civic Education. JPI (Jurnal Pendidikan Indonesia), 9(3), 401. https://doi.org/10.23887/jpi-undiksha.v9i3.21565.

Prihanto, D. A., \& Yunianta, T. N. H. (2018). Pengembangan Media Komik Matematikapada Materi Pecahan Untuk Siswa Kelas V Sekolah Dasar. MAJU: Jurnal Ilmiah ..., 5(1), 79-90.

Purwanti, E., Palupi, R. Z. P., Galuh, A., \& Rianingsih, D. (2020). Pengembangan Instrumen Penilaian Keterampilan Abad 21. CV Kota Tua Jalan Sanan.

Putri, N. P. J. E., Artini, L. P., \& Wahyuni, L. G. E. (2020). EFL Teachers' Perception and Strategies for Integrating Character Education into the Lesson. Jurnal Pendidikan Dan Pengajaran, 53(1), 1. https: //doi.org/10.23887/jpp.v53i1.19172.

Qomariyah, S. N. (2019). Effect of Problem Based Learning Learning Model to Improve Student Learning Outcomes. International Journal of Educational Research Review, 4(2), 217-222. https://doi.org/10.24331/ijere.518056. 
Ramadhani, S. (2017). Efektivitas Metode Pembelajaran SCL (Student Centered Learning) dan TCL (Teacher Centered Learning) Pada Motivasi Instrinsik \& Ekstrinsik Mahasiswa Psikologi Untag Surabaya Angkatan Tahun 2014 - 2015. Jurnal Psikologi Indonesia, 6(2), 66-74.

Rienties, B., Lewis, T., McFarlane, R., Nguyen, Q., \& Toetenel, L. (2018). Analytics in online and offline language learning environments: the role of learning design to understand student online engagement. Computer Assisted Language Learning, 31(3), 273-293. https: //doi.org/10.1080/09588221.2017.1401548.

Rosidin, U., Kadaritna, N., \& Hasnunidah, N. (2019). Can argument-driven inquiry models have impact on critical thinking skills for students with differentpersonality types? Cakrawala Pendidikan, 38(3), 511-526. https://doi.org/10.21831/cp.v38i3.24725.

Rusmono, \& Alghazali, M. I. (2019). Pengaruh Media Cerita Bergambar Dan Literasi Membaca Terhadap Hasil Belajar Siswa Sekolah Dasar. JTP - Jurnal Teknologi Pendidikan, 21(3), 269-282. https://doi.org/10.21009/jtp.v21i3.13386.

Rustam E, S., Sidabutar, D. R., \& Edy, S. (2017). Improving Learning Activity and Students ' Problem Solving Skill through Problem Based Learning (PBL) in Junior High School. International Journal of Sciences: Basic and Applied Research (IJSBAR), 33(2), 321-331.

Santi, D. P. D., Maharani, A., \& Setiyani. (2019). Analisa Kesalahan Konsep Materi Pecahan Pada Mahasiswa Calon Guru Sd Universitas Swadaya Gunung Jati Cirebon. Elementary School Education Journal, 3(1), 93-103.

Santoso, S. (2019). Mahir Statistik Parametrik.

Sari, D. A. R. P., Tegeh, I. M., \& Pudjawan, K. (2020). Model Pembelajaran Value Clarification Technique Berbantuan Media Microsoft Powerpoint Untuk Meningkatkan Hasil Belajar PKn. Jurnal Edutech Undiksha, 8(2), 183. https://doi.org/10.23887/jeu.v8i2.29071.

Seibert, S. A. (2021). Problem-based learning: A strategy to foster generation Z's critical thinking and perseverance. Teaching and Learning in Nursing, 16(1), 85-88. https://doi.org/10.1016/j.teln.2020.09.002.

Shin, M., \& Bolkan, S. (2021). Intellectually stimulating students ' intrinsic motivation: the mediating influence of student engagement, self-efficacy, and student academic. Communication Education, O(0), 1-19. https://doi.org/10.1080/03634523.2020.1828959.

Siang, J. L., Nurdin, I., \& Rusmono. (2017). Pengembangan Paket Modul Cetak Mata Pelajaran Pendidikan Agama Kristen SMP Negeri Tidore Kepulauan. Jurnal Teknologi Pendidikan, 19(3), 191-205.

Sökmen, Y. (2019). The role of self-efficacy in the relationship between the learning environment and $\begin{array}{llll}\text { student engagement. } & \text { Educational 19. }\end{array}$ https: //doi.org/10.1080/03055698.2019.1665986.

Solihatin, E. (2017). Pengaruh Pembelajaran Berbasis Internet dan Konsep Diri Terhadap Hasil Peer Teaching. JTP - Jurnal Teknologi Pendidikan, 19(1), 17-32.

Suarsana, I. M., \& Pujawan, I. G. N. (2017). Pendidikan dan Latihan Pembelajaran Pecahan Bagi Guru-Guru Sekolah Dasar Gugus V Kecamatan Kubu. Widya Laksana, 6(1), 52-61.

Surya, E., \& Syahputra, E. (2017). Impact of Indonesian Realistic Mathematics Approach to Students Mathematic Disposition on Chapter Two Composition Function and Invers Fungtion in Grade XI IA-1 SMA Negeri 4 Padangsidimpuan. International Journal of Novel Research in Education and Learning, 4(2), 93-100.

Ulya, H., \& Rahayu, R. (2021). Hubungan Keterampilan Proses Berpikir Matematis Dengan Hasil Belajar Mahasiswa. AKSIOMA: Jurnal Program Studi Pendidikan Matematika, 10(1), 262-272.

Usman Fauzan, A., \& Aldila Afriansyah, E. (2017). Kemampuan Pemahaman Matematis Siswa Melalui Model Pembelajaran Auditory Intellectualy Repetition dan Problem Based Learning. Jurnal Pendidikan Matematika, 11(1), 68-78.

Wahyuni, M. (2020). Statistik Deskriptif Untuk Penelitian Olah Data Manual dan SPSS 25. CV. Bintang Surya Madani.

Yulianto, T., Pramudya, I., \& Slamet, I. (2019). Effects of the 21st Century Learning Model and ProblemBased Models on Higher Order Thinking Skill Effects of the 21st Century Learning Model and Problem-Based Models on Higher Order Thinking Skill. International Journal of Educational Research Review, Special, 749-755. https://doi.org/10.24331/ijere.629084.

Zhou, Z. (2018). An Empirical Study on the Influence of PBL Teaching Model on College Students' Critical Thinking Ability. English Language Teaching, 11(4), 15. https://doi.org/10.5539/elt.v11n4p15. 